\title{
Prevalence of Toxoplasma gondii in Chicken samples from delta of Egypt using ELISA, histopathology and immunohistochemistry
}

\author{
Hany M. Ibrahim - Fathy Abdel-Ghaffar • Gamalat Y. Osman • \\ Safinaz H. El-Shourbagy • Yoshifumi Nishikawa • Reham A. Khattab
}

Received: 11 March 2014/ Accepted: 12 August 2014/Published online: 31 August 2014

(C) Indian Society for Parasitology 2014

\begin{abstract}
Estimates of the zoonotic diseases are helpful for monitoring and improving public health. Laboratorybased surveillance provides crucial information for assessing zoonotic disease trends and developments. Toxoplasmosis is considered as a zoonotic disease and has both medical and veterinary importance since it leads to abortion in humans and several animal species. In view of the worldwide importance of $T$. gondii, this study aimed to estimate the prevalence of $T$. gondii in chickens from the Delta of Egypt. A total of 304 blood and brain samples were collected from Egyptian chickens from Gharbiya, Qalyoubiya, Minufiya, Beheira, Kafr EL-Shaykh and Dakahlia Provinces. In order to determine the serological and histopathological prevalence of $T$. gondii, the samples were examined by ELISA, histopathology and immunohistochemistry (IHC). The prevalence of $T$. gondii was 11.18 , $6.91,6.91 \%$ by ELISA, histopathology and IHC, respectively. Statistically significant differences in the prevalence of $T$. gondii were observed on the basis of season, sex and
\end{abstract}

H. M. Ibrahim ( $₫)$ · G. Y. Osman · R. A. Khattab

Department of Zoology, Faculty of Science, Minufiya

University, Shebin El-Kom, Egypt

e-mail: hanyibrahimeg@gmail.com

F. Abdel-Ghaffar

Department of Zoology, Faculty of Science, Cairo University, Giza, Egypt

S. H. El-Shourbagy

Department of Pathology, Faculty of Medicine, Tanta

University, Tanta, Egypt

\section{Y. Nishikawa}

National Research Center for Protozoan Diseases, Obihiro University of Agriculture and Veterinary Medicine, Inada-cho, Obihiro, Hokkaido, Japan habitat. These data provide valuable information regarding the epidemiology of $T$. gondii infections in Egyptian chickens, which can be employed in developing efficient strategies for disease management and control.

Keywords Toxoplasmosis - Prevalence .

Immunohistochemistry · ELISA · Chicken $\cdot T g S A G 2$

\section{Introduction}

Toxoplasma gondii is protozoan parasite and one of the world's most common parasites. It has an indirect life cycle with cat as the definitive host and can infect a wide range of animal species. In the host, $T$. gondii can cause abortion or neonatal mortalities (Dubey and Beattie 1988). In animals, T. gondii infection not only results in significant reproductive losses, and hence economic losses, but also has implications for public health since consumption of infected meat can facilitate zoonotic transmission (Tenter et al. 2000; CDC 2004). Although it is not normally a significant problem for healthy humans, $T$. gondii infection can be life threatening for infants infected congenitally, immunocompromised and immunodeficient patients, as a result of either acute infection or reactivation of infection (Luft and Remington 1988; Chintana et al. 1998; Aspinall et al. 2003).

Diagnoses of toxoplasmosis in birds can be made by finding parasites in impression smears or histological sections of organs from affected animals or in organs and fluids from susceptible avian hosts (Springer 1991). Brain and other tissues were fixed in $10 \%$ neutral-buffered formalin, processed routinely for sectioning and stained with hematoxylin and eosin (Dubey et al. 2007). In addition, diagnoses of toxoplasmosis in chickens are aided by 
immunohistochemical staining procedures that use $T$. gondii polyclonal rabbit antibodies to detect parasites in formalin-fixed, paraffin-embedded brain specimens (Dubey et al. 2001).

Serological testing is an important method for detecting T. gondii infection, and includes the indirect fluorescent antibody test (IFAT), enzyme linked immunosorbent assay (ELISA), competitive-inhibition ELISA, Western blotting, and direct agglutination test using intact tachyzoite or tachyzoite-derived antigens (Huang et al. 2004). The molecular search for diagnostic antigens for $T$. gondii infection has been focused on the identification of immunodominant antigens that are recognized by sera from animals infected with geographically distant isolates and from both acute and chronically infected animals. The surface antigen 2 of $T$. gondii (TgSAG2), expressed either in Escherichia coli or insect cells, was validated as a useful antigen and promises a highly sensitive and specific ELISA (Huang et al. 2002a, b).

In previous reports from Egypt, T. gondii antibodies were detected in asymptomatic pregnant women (Azab et al. 1993; Ibrahim et al. 2009), turkeys, ducks (El-Massey et al. 2000; Dubey et al. 2003), ostrich (El-Madawy and Metawea 2013), water buffaloes (Dubey et al. 1998), cattle (Ibrahim et al. 2009), horses (Ghazy et al. 2007), donkeys (El-Ghaysh 1998) and camels (Hilali et al. 1998).

The aim of this study was to estimate the prevalence of T. gondii in chickens from different regions in the delta of Egypt by different diagnostic methods as an indicator of soil contamination due to $T$. gondii oocysts.

\section{Materials and methods}

Parasite and cell cultures

The $T$. gondii (RH strain) tachyzoites were maintained on monkey kidney adherent fibroblasts (Vero cells) cultured in Eagle's minimum essential medium (EMEM, Sigma, St Louis, MO) supplemented with $8 \%$ heat-inactivated fetal bovine serum. For the purification of tachyzoites, parasites and host-cell debris were washed in cold phosphate buffer saline (PBS), and the final pellet was resuspended in cold PBS and passed through a 27-gauge needle and a 5.0- $\mu \mathrm{m}$ pore filter (Millipore, Bedford, MA).

\section{Samples}

A total of 304 chickens (Gallus domesticus) were obtained during winter, autumn and spring, 2011, from different Provinces of the Delta of Egypt. Ninety seven free-range chickens were purchased (with consideration on sex) from three villages belong to Provinces of Qalyoubiya, Minufiya and Gharbiya. A total of 207 caged chickens (with consideration on sex) were also obtained from bird slaughterhouses and they rose in farms from Provinces of Gharbiya, Beheira, Kafr EL-Shaykh and Dakahlia. Blood was collected from the brachial wing vein of individual chicken, incubated at room temperature for $1 \mathrm{~h}$, and then centrifuged at $1,000 \times g$ for $10 \mathrm{~min}$, and the serum was collected and stored at $-20{ }^{\circ} \mathrm{C}$. Brains were removed from each bird and fixed in neutral buffered formalin $10 \%$ for $24 \mathrm{~h}$ for tissue cyst detection.

\section{Antigens}

The template DNA for polymerase chain reaction (PCR) was extracted from tachyzoites of $T$. gondii $\mathrm{RH}$ strain (Dubey and Frenkel 1988; Huang et al. 2004; Ibrahim et al. 2009). Two oligonucleotide primers, 5'-ACGAATTCGT CCACCACCGAGACG-3' and 5'-ACGAATTCTTACT TGCCCGTGAGA-3', which correspond to amino acids 75 to 221, were used to amplify the truncated SAG2 (TgSAG2t) gene, without sequences encoding a highly hydrophobic signal peptide and C-terminus, by PCR (Parmley et al. 1992; Huang et al. 2004). The TgSAG2t gene was inserted into EcoRI site of the bacterial expression vector, pGEX-4T-3 (Promega, Madison, WI). The resulting plasmid was designated as pGEX/TgSAG2t. pGEX/TgSAG2t was expressed as glutathione S-transferase (GST) fusion protein (GST-TgSAG2t) in Esherichia coli (DH5 $\alpha$ strain) and the proteins were purified by glutathione Sepharose 4B (Amersham Pharmacia Biotech) and analyzed by sodium dodecyl sulfate-polyacrylamide gel electrophoresis (Ibrahim et al. 2009).

\section{ELISA}

ELISA was performed according to Ibrahim et al. (2009). The plates were coated using the recombinant antigens (GST-TgSAG2t, or GST, $5 \mu \mathrm{g} / \mathrm{ml}$ ), produced as described earlier, in a coating buffer $(50 \mathrm{mM}$ carbonate) and incubated overnight at $4{ }^{\circ} \mathrm{C}$. After washing once with washing buffer (PBS containing $0.05 \%$ Tween 20), the plates were blocked with blocking solution (PBS containing $3 \%$ skim milk) at $37{ }^{\circ} \mathrm{C}$ for $2 \mathrm{~h}$. After washing once with washing buffer, $50 \mu \mathrm{l}$ of serum diluted $(1: 100)$ in blocking solution was added to duplicate wells for each sample and then incubated at $37{ }^{\circ} \mathrm{C}$ for $1 \mathrm{~h}$. After washing six times with washing buffer, the plates were incubated with $50 \mu \mathrm{l}$ of horseradish peroxidase (HRPO)-conjugated rabbit antichicken Immunoglobulin G (Invitrogen, Camarillo, CA), diluted in blocking solution (1:4000) per well at $37{ }^{\circ} \mathrm{C}$ for $1 \mathrm{~h}$. After washing six times with washing buffer, the plates were incubated with $100 \mu \mathrm{l}$ substrate 2,2'-azino-bis(3ethylbenzthiazoline-6-sulphonic acid (ABTS)) in an ABTS 
buffer ( $0.1 \mathrm{M}$ citric acid, $0.2 \mathrm{M}$ sodium phosphate) per well at room temperature for $1 \mathrm{~h}$. The absorbance at $405 \mathrm{~nm}$ was measured using a microplate reader (Seac, Radim Company, Italy). The ELISA results were determined by the difference in mean optical densities at a value of $405 \mathrm{~nm}\left(\mathrm{OD}_{405}\right)$ between the recombinant antigen ( $T g$ SAG2t) and the GST protein. The cut off values were determined as the $\mathrm{OD}_{405}$ value for $T$. gondii negative sera plus two standard deviations; $T g$ SAG2t: 0.017 in chickens $(n=20)$. The negative sera from sera stock were tested and confirmed negative by western blot and IFAT and their representative brain samples were free from the tissue cyst.

Histopathological and immunohistochemical examinations

Brains were fixed in $10 \%$ neutral-buffered formalin, processed routinely for sectioning and stained with hematoxylin and eosin $\mathrm{H}$ and $\mathrm{E}$. The sections were examined under a light microscope and the tissue cysts were scored.

Sections of brain were reacted with antibodies to $T$. gondii polyclonal rabbit antibodies according to the manufacturer's instructions (Thermo Scientific, CA). Immunohistochemistry (IHC) was done as described by (Lindsay and Dubey 1989; Dubey et al. 2001). The polyclonal $T$. gondii antibodies react specifically with both tachyzoites and bradyzoites of $T$. gondii.

\section{Statistical analysis}

The Chi square test was used to evaluate significant differences $(P<0.05)$ of infection rate in animals of different habitat, sex, locations and season of the sample collection. Means in the same columns assigned with the different letter show significant differences between these values $P<0.05$.

\section{Results}

The prevalence of $T$. gondii in chickens from different Provinces of the delta of Egypt was summarized in
Table 1. The overall prevalence of $T$. gondii was 11.18, 6.91, 6.91\% in chicken, using ELISA, histopathology and IHC, respectively. The results of IHC confirmed the histopathology results. According to the region, the prevalence was significantly $(P<0.05)$ high in Qalyoubiya and Kafr EL-Shaykh Provinces with values of $17.64 \%(6 / 34)$ and $14.75 \%(9 / 61)$ by ELISA and $14.70 \%(5 / 34)$ and $9.83 \%(6 / 61)$ using IHC, respectively. No significant differences were detected between Qalyoubiya and Kafr ELShaykh Provinces. Moreover, the prevalence was high in Gharbiya Province with values of $12.38 \%$ (13/105), and $6.66 \%(7 / 105)$ by ELISA and IHC, respectively. In spite of the high prevalence in Gharbiya Province, significant decrease was observed in Gharbiya Province when compared to Qalyoubiya Province using ELISA and IHC. Moreover, the prevalence was significantly $(P<0.05)$ low in Minufiya and Dakahlia as compared to Qalyoubiya and Kafr EL-Shaykh Provinces using ELISA and IHC and as compared to Gharbiya Province using only ELISA. No positive chickens were detected in Beheira Province.

The results of ELISA, histopathology and IHC were summarized in Table 2. The results of ELISA were concordant with those of histopathology and IHC; $95.72 \%$. Histopathology results were completely concordant with those of IHC; $100 \%$.

According to the season, the prevalence of $T$. gondii in chickens was illustrated in Table 3 . The prevalence during the seasons of the sample collection, using ELISA, was highest in the autumn $13.54 \%$, followed by spring $11.9 \%$. During winter the prevalence was significantly $(P<0.05)$ reduced $8.87 \%$ compared to the autumn season. On the other hand, no significant differences were detected in spring as compared to either winter or autumn using ELISA. Furthermore, no significant differences were detected on the seasonal prevalence of $T$. gondii using histopathology or IHC.

On the basis of the sex, the seroprevalence was significantly $(P<0.05)$ higher in females $11.52 \%(31 / 269)$ compared to male birds $8.57 \%$ (3/35). Presence of $T$. gondii was not significant $(P>0.05)$ using histopathology or IHC (Table 3 ). In relation to the habitat $T$. gondii
Table 1 Prevalence of $T$. gondii infection in chickens from different provinces of Delta of Egypt using different diagnostic methods

* Significant difference $(P<0.05$, Chi square test $)$

Means in the same columns assigned with the same letter show insignificant differences between these values $P>0.05$

\begin{tabular}{|c|c|c|c|c|}
\hline \multirow[t]{2}{*}{ Province } & \multicolumn{2}{|l|}{ Total } & \multicolumn{2}{|l|}{ Positive (\%) } \\
\hline & Examined & ELISA & Histopathology & IHC \\
\hline Qalyoubiya & 34 & $6(17.64)^{\mathrm{a}}$ & $5(14.70)^{\mathrm{a}}$ & $5(14.70)^{\mathrm{a}}$ \\
\hline Kafr EL-Shaykh & 61 & $9(14.75)^{\mathrm{ab}}$ & $6(9.83)^{\mathrm{ab}}$ & $6(9.83)^{\mathrm{ab}}$ \\
\hline Gharbiya & 105 & $13(12.38)^{\mathrm{b}^{*}}$ & $7(6.66)^{\mathrm{bc}^{*}}$ & $7(6.66)^{b c^{*}}$ \\
\hline Minufiya & 24 & $2(8.33)^{\mathrm{c}^{*}}$ & $1(4.16)^{\mathrm{c}^{*}}$ & $1(4.16)^{\mathrm{c}^{*}}$ \\
\hline Dakahlia & 49 & $4(8.16)^{\mathrm{c}^{*}}$ & $2(4.08)^{\mathrm{c}^{*}}$ & $2(4.08)^{\mathrm{c}^{*}}$ \\
\hline Beheira & 31 & $0(0.00)^{\mathrm{d}^{*}}$ & $0(0.00)^{\mathrm{d}^{*}}$ & $0(0.00)^{\mathrm{d}^{*}}$ \\
\hline Total & 304 & 34 (11.18) & $21(6.91)$ & $21(6.91)$ \\
\hline
\end{tabular}


Table 2 Summary on the detection of $T$. gondii infections in ELISA, histopathology and IHC

\begin{tabular}{lllllllll}
\hline Toxoplasma gondii & \multirow{2}{*}{ ELISA $^{\mathrm{a}}$} & & \multicolumn{2}{l}{ Histopathology } & & \multicolumn{2}{l}{$\mathrm{IHC}^{\mathrm{c}}$} \\
& & & $(+)$ & $(-)$ & & $(+)$ & $(-)$ \\
\hline & $(+)$ & 34 & 21 & 13 & & 21 & 13 \\
& $(-)$ & 270 & 0 & 270 & & 0 & 270 \\
& Total & 304 & 21 & 283 & & 21 & 283
\end{tabular}

a The frequencies of positive and negative samples as results of ELISA

b The frequencies of positive and negative samples as results of histopathology cross-tabulated with ELISA results

c The frequencies of positive and negative samples as results of IHC cross-tabulated with ELISA results

Table 3 Prevalence of $T$. gondii infection in chickens of Delta of Egypt using ELISA, Histopathology and IHC according to period of the year, gender, and habitat

\begin{tabular}{lccc}
\hline Variable & ELISA $(\%)$ & Histopathology $(\%)$ & IHC $(\%)$ \\
\hline \multicolumn{2}{l}{ Period of the year } & & \\
Autumn & $13.54^{\mathrm{a}}$ & $7.29^{\mathrm{a}}$ & $7.29^{\mathrm{a}}$ \\
Spring & $11.90^{\mathrm{a}}$ & $7.14^{\mathrm{a}}$ & $7.14^{\mathrm{a}}$ \\
Winter & $8.87^{\mathrm{b}^{*}}$ & $6.45^{\mathrm{a}}$ & $6.45^{\mathrm{a}}$ \\
Gender & & & \\
Female & $11.52^{\mathrm{a}}$ & $7.06^{\mathrm{a}}$ & $7.06^{\mathrm{a}}$ \\
Male & $8.57^{\mathrm{b}^{*}}$ & $5.71^{\mathrm{a}}$ & $5.71^{\mathrm{a}}$ \\
Habitat & & & \\
Free range & $16.49^{\mathrm{a}}$ & $11.34^{\mathrm{a}}$ & $11.34^{\mathrm{a}}$ \\
Caged & $8.69^{\mathrm{b}^{*}}$ & $4.83^{\mathrm{b}^{*}}$ & $4.83^{\mathrm{b}^{*}}$ \\
\hline
\end{tabular}

Means in the same columns assigned with the same letter show insignificant differences between these values $P>0.05$

* Significant difference $(P<0.05$, Chi square test $)$

antibodies and tissue cysts were detected in both free-range and caged chickens (Table 3). The prevalence showed significant $(P<0.05)$ increase in free-range chickens $16.49 \%(16 / 97), 11.34 \%(11 / 97)$ compared to caged chickens $8.69 \%$ (18/207), $4.83 \%$ (10/207) using ELISA and IHC, respectively.

\section{Discussion}

Direct detection of $T$. gondii oocysts in soil is difficult. Therefore, chickens have been used as one of indicators of soil contamination with $T$. gondii oocyst (Dubey, 2010). Prevalence of $T$. gondii in 304 chickens in different provinces of the delta of Egypt, were detected by ELISA, histopathology and IHC with values of 11.18, 6.91 and $6.91 \%$, respectively. Prevalence was significantly high in Qalyoubiya and Kafr EL-Shaykh Provinces when compared to Minufiya and Dakahlia Provinces. Significant decrease was demonstrated in Gharbiya Province when compared to Qalyoubiya Province using ELISA and IHC. On contrary, significant increase was detected in Gharbiya Province when compared to Minufiya and Dakahlia Provinces using ELISA. No positive chickens were detected in Beheira Province. Dubey et al. (2003) detected higher prevalence of $T$. gondii, $40.4 \%$, using the modified agglutination test (MAT) in chickens from rural area surrounding Giza (south of Cairo), Egypt. Also using MAT, seroprevalence of $T$. gondii infection in chickens was $13.95 \%$, in Beni-Suef area, south of Egypt (Aboelhadid et al. 2013). In addition, among turkeys, chickens, and ducks the seroprevalence was 59.5, 47.2, and $50 \%$, respectively, in Giza, Egypt (El-Massey et al. 2000).

In particular, serological assays detected higher prevalence than detection of the parasites in the host tissues, although the results of histopathology and IHC were highly concordant with those of ELISA. These can be explained by level of infection in chicken examined samples may be under the detectable level and low parasitemia makes the diagnosis by microscopic examination difficult. Moreover, the antibody response may be independent of parasite burden. Hill et al. (2006) reported that a serum-based ELISA is the more sensitive than PCR, and animal bioassays for detection of $T$. gondii infected swine. A similar observation had been made in pigs infected with various doses of Trichinella spiralis (Murrell et al. 1986). It is likely that the low reliability of the histological and IHC assays results come from the limited sample size, random distribution of tissue cysts, and perhaps low numbers of $T$. gondii tissue cysts in the tested chicken tissues.

Chickens used in this study are 45-60 days old and the collections of the samples were done at the end of each season, meaning the birds were born, lived and die during the same season of the samples collection. In this study the lowest seroprevalence of $T$. gondii was recorded in the winter season. In contrast the seasonal prevalence was higher in the autumn and spring using ELISA. No significant differences were detected on the seasonal prevalence of $T$. gondii using histopathology and IHC. Environmental conditions are important for oocyst survival. Prevalence of Toxoplasma is higher in humid tropical areas (Meerburg and Kijlstra 2009) and lowers in arctic areas (Tenter et al. 2000). The delta of Egypt experiences its lower temperatures during the winter where temperature decrease, It normally in the range of $9{ }^{\circ} \mathrm{C}$ at nights to $19{ }^{\circ} \mathrm{C}$ at days. While spring and autumn in the delta of Egypt appears warmer than the winter season. Accumulation of $T$. gondii oocysts may be most important in spring, summer and early autumn, when temperatures are suitable for sporulation (Simon et al. 2013).

Although no significant association was found to occur between the presence of $T$. gondii and gender in chickens 
from the delta of Egypt using histopathology and IHC, the results of ELISA showed significantly higher prevalence in females compared to male birds. Similar results were obtained by Tasawar et al. (2013) in cattle, and Jittapalapong et al. (2005) in goats. Our observation in chickens might be associated to difference in the behaviour of the male and female chickens or to management differences. More studies are required in order to corroborate this finding.

Specific antibodies and tissue cysts to $T$. gondii were found in 16.49 and $11.34 \%$ of the free-range chickens and in 8.69 and $4.83 \%$ of the caged chickens using ELISA and IHC, respectively, indicating that free-range chickens have more chance to get infected by $T$. gondii. Infection rate to T. gondii in free-range chickens is comparable to that found in other countries (Dubey et al. 2008; Zhu et al. 2008; Yan et al. 2009). Evidence is accumulating that transmission by oocysts may be more prevalent than initially realized, at least in some parts of the world (Dubey 2010). In Egypt, the main risk factor associated with chicken seropositivity might be the contact with soil-harboring oocysts from homeless cats (Ibrahim et al. 2009). The detected prevalence of $T$. gondii in chicken indicated soil contamination due $T$. gondii oocysts because free range chickens feed from the ground, and suggested that the meat from poultry might be an important source of infection to human.

In conclusion, the current data indicated that $T$. gondii infection is widely distributed in delta of Egypt. ELISA, using recombinant $T g S A G 2 t$, is a sensitive diagnostic method for the detection of $T$. gondii antibodies in chickens.

Acknowledgments The authors thank the local veterinary practitioners for collecting blood and brain samples.

Conflict of interest The Authors declares no conflict of interest related to this work.

\section{References}

Aboelhadid SM, Abdel-Ghany AE, Ibrahim MA, Mahran HA (2013) Seroprevalence of Toxoplasma gondii infection in chickens and humans in Beni Suef. Egypt Glob Vet 11(2):139-144

Aspinall TV, Guy EC, Roberts KE, Joynson DH, Hyde JE, Sims PF (2003) Molecular evidence for multiple Toxoplasma gondii infections in individual patients in England and Wales: public health implications. Int J Parasitol 33(1):97-103

Azab ME, el-Shenawy SF, el-Hady HM, Ahmad MM (1993) Comparative study of three tests (indirect haemagglutination, direct agglutination, and indirect immuno-fluorescence) for detection of antibodies to Toxoplasma gondii in pregnant women. J Egypt Soc Parasitol 23(2):471-476

Centers of disease control and prevention (CDC) (2004) Toxoplasmosis. pp. 11-22
Chintana T, Sukthana Y, Bunyakai B, Lekkla A (1998) Toxoplasma gondii antibody in pregnant women with and without HIV infection. Southeast Asian. J Trop Med Public Health 2:383-386

Dubey JP (2010) Toxoplasma gondii infections in chickens (Gallus domesticus): prevalence, clinical disease, diagnosis and public health significance. Zoonoses Public Health 57(1):60-73

Dubey JP, Beattie CP (1988) Toxoplasmosis of animals and man, CRC Press, p. 219

Dubey JP, Frenkel JK (1988) Toxoplasmosis of rats: a review, with considerations of their value as an animal model and their possible role in epidemiology. Vet Parasitol 77:1-32

Dubey JP, Romand S, Hilali M, Kwok OC, Thulliez P (1998) Seroprevalence of antibodies to Neospora caninum and Toxoplasma gondii in water buffaloes (Bubalus bubalis) from Egypt. Int J Parasitol 28(3):527-529

Dubey JP, Garner MM, Willette MM, Batey KL, Gardiner CH (2001) Disseminated toxoplasmosis in magpie geese (Anseranas semipalmata) with large numbers of tissue cysts in livers. J Parasitol 87(1):219-223

Dubey JP, Graham DH, Dahl E, Hilali M, El-Ghaysh A, Sreekumar C, Kwok OC, Shen SK, Lehmann T (2003) Isolation and molecular characterization of Toxoplasma gondii from chickens and ducks from Egypt. Vet Parasitol 114(2):89-95

Dubey JP, Webb DM, Sundar N, Velmurugan GV, Bandini LA, Kwok OCH, Su C (2007) Endemic avian toxoplasmosis on a farm in Illinois: clinical disease, diagnosis, biologic and genetic characteristics of Toxoplasma gondii isolates from chickens (Gallus domesticus), and a goose (Anser anser). Vet Parasitol 148:207-212

Dubey JP, Huong LT, Lawson BW, Subekti DT, Tassi P, Cabaj W, Sundar N, Velmurugan GV, Kwok OC, Su C (2008) Seroprevalence and isolation of Toxoplasma gondii from free-range chickens in Ghana, Indonesia, Italy, Poland, and Vietnam. J Parasitol 94(1):68-71

El-Ghaysh A (1998) Seroprevalence of Toxoplasma gondii in Egyptian donkeys using ELISA. Vet Parasitol 80(1):71-73

El-Madawy SR, Metawea FY (2013) Serological assays and PCR for detection of Toxoplasma gondii infection in an ostrich farm at Ismailia Provine,Egypt. IOSR J Agric Vet Sci 2(3):56-60

El-Massey A, Mahdy OA, El-Ghaysh A, Dubey JP (2000) Prevalence of Toxoplasma gondii antibodies from sera of turkeys, chickens, and ducks from Egypt. J Parasitol 32:99-105

Ghazy AA, Shaapan RM, Abdel-Rahman EH (2007) Comparative serological diagnosis of toxoplasmosis in horses using locally isolated Toxoplasma gondii. Vet Parasitol 145:31-36

Hilali M, Romand S, Thulliez P, Kwok OC, Dubey JP (1998) Prevalence of Neospora caninum and Toxoplasma gondii antibodies in sera from camels from Egypt. Vet Parasitol 75(2-3):269-271

Hill DE, Chirukandoth S, Dubey JP, Lunney JK, Gamble HR (2006) Comparison of detection methods for Toxoplasma gondii in naturally and experimentally infected swine. Vet Parasitol 141(1-2):9-17

Huang X, Xuan X, Kimbita EN, Battur B, Miyazawa T, Fukumoto S, Mishima M, Makala LH, Suzuki H, Sugimoto C, Nagasawa H, Fujisaki K, Mikami T, Igarashi I (2002a) Development and evaluation of an enzyme-linked immunosorbent assay with recombinant SAG2 for diagnosis of Toxoplasma gondii infection in cats. J Parasitol 88:804-807

Huang X, Xuan X, Suzuki H, Sugimoto C, Nagasawa H, Fujisaki K, Mikami T, Igarashi I (2002b) Characterization of Toxoplasma gondii SAG2 expressed in insect cells by recombinant baculovirus and evaluation of its diagnostic potential in an enzyme-linked immunosorbent assay. Clin Diagn Lab Immunol 9:1343-1347

Huang X, Xuan X, Hirata H, Yokoyama N, Xu L, Suzuki N, Igarashi I (2004) Rapid immunochromatographic test using recombinant 
SAG2 for detection of antibodies against Toxoplasma gondii in cats. J Clin Microbiol 42:351-353

Ibrahim HM, Huang P, Salem TA, Talaat RM, Nasr MI, Xuan X, Nishikawa Y (2009) Prevalence of Neospora caninum and Toxoplasma gondii antibodies in northern Egypt. Am J Trop Med Hyg 80(2):263-267

Jittapalapong S, Sangvaranond A, Pinyopanuwat N, Chimnoi W, Khachaeram S, Koizumi S, Maruyama S (2005) Seroprevalence of Toxoplasma gondii infection in domestic goats in Satun Province, Thailand. Vet Parasitol 127(1):17-22

Lindsay DS, Dubey JP (1989) Immunohistochemical diagnosis of Neospora caninum in tissue section of dogs. Am J Vet Res 50(11):1981-1983

Luft BJ, Remington JS (1988) AIDS commentary, Toxoplasmic encephalitis. J Infect Dis 157(1):1-6

Meerburg BG, Kijlstra A (2009) Changing climate-changing pathogens: Toxoplasma gondii in North-Western Europe. Parasitol Res 105:17-24

Murrell KD, Anderson WR, Schad GA, Hanbury RD, Kaza-cos KR, Brown J, Gamble HR (1986) Field evaluation of the ELISA test for swine trichinosis: efficacy of the excretory-secretory antigen. Am J Vet Res 47:1046-1049

Parmley SF, Sgarlato GD, Mark J, Prince JB, Reminaton JS (1992) Expression, characterization, and serological reactivity of recombinant surface antigen P22 of Toxoplasma gondii. J Clin Microbiol 30:1127-1133

Simon A, Poulin MB, Rousseau AN, Ogden NH (2013) Fate and Transport of Toxoplasma gondii oocysts in seasonally snow covered watersheds: a conceptual framework from a melting snowpack to the Canadian Arctic Coasts. Int J Environ Res Public Health 10:994-1005

Springer WT (1991) Protozoa. Other blood and tissue protozoans. In: Diseases of poultry, ed. by Calnek BW, Barnes HJ, Beard, CW, et al., 9th ed., (Iowa State University Press, Ames), pp. 821-824

Tasawar Z, Shafiq Z, Lashari MH, Aziz F (2013) Seroprevalence of Toxoplasma gondii in Cattle, Punjab. Pak Glob Vet 11(5):681-684

Tenter AM, Heckeroth AR, Weiss LM (2000) Toxoplasma gondii: from animals to humans. Int J Parasitol 30:1217-1258

Yan C, Yue CL, Yuan ZG, He Y, Yin CC, Lin RQ, Dubey JP, Zhu XQ (2009) Toxoplasma gondii infection in domestic ducks, freerange and caged chickens in southern China. Vet Parasitol 165:337-340

Zhu J, Yin J, Xiao Y, Jiang N, Ankarlev J, Lindh J, Chen Q (2008) A sero-epidemiological survey of Toxoplasma gondii infection in free-range and caged chickens in northeast China. Vet Parasitol $158: 360-363$ 